\title{
CONSTRUCTIVE TRUSTS AND BANK COLLECTIONS
}

\author{
WAYNE L. TOWNSEND
}

The power of an owner of personal property to follow that property in the hands of a wrongdoer and recover the same in specie is explained by the history of replevin. Doctrines of the tortious confusion of goods simply amplify the same general theme. Where the peculiar nature of the chattel has called for restoration of the exact thing in order to do complete justice, the power has, for two and a half centuries at least, been successfully asserted in equity. ${ }^{1}$ And if the chattel has been exchanged for another commodity which can be identified while in the wrongdoer's possession the reclamation of the substituted form of the original property has long been vindicated at $\mathrm{law}^{2}$ and in equity. The sanction of peaceful self-help in such a case won the approval of Lord Ellenborough on the ground that, as long as the substitute remained in the wrongdoer's possession, the wronged party "never ceased to be the lawful proprietor." " Properly to redress the owner's injury, equity erects a constructive trust of the substitute, and so long as the substitute is not dissipated or transferred to a bona fide purchaser but one limitation restrains the exercise of the owner's power-the necessity of identification..$^{\circ}$

When the substitute took the form of money, the courts in the earlier cases were of opinion that equity could not follow the money and decree restitution as money "has no earmark." o This attitude Lord Ellenborough took care to correct when he said, ". . . the dictum that money has no earmark must be under-

\footnotetext{
1 Pusey v. Pusey, 1 Vern. 273 (1684); Duke of Somerset v. Cookson, 3 P. Wms. 390 (1735).

2 The power of following the proceeds of the conversion process is, of course, available to the owner when the person in possession has, in an authorized manner, disposed of the chattel and the proceeds have been retained in his estate until death or bankruptcy. Burdett v. Willett, 2 Vern. 638 (1708) (sale by factor on credit; payment decreed to principal); Garratt v. Cullum, Buller N.P. 42 (1709) (same); Whitecomb v. Jacob, 1 Salk. 160 (1711) (proceeds of sale by factor invested in goods; goods held property of principal); Scott v. Surman, Willes 400 (1742) (sale by factor; payment in notes of buyer; notes and bounty money held property of principal).

3 Ryall v. Ryall, 1 Atk. 59 (1739).

4 Taylor v. Plumer, 3 M. \& S. 562 (1815).

- \$TORY, EQUITY JURISPRUDENCE (1st ed. 1836) \$\$ 1258-1259.

6 Whitcomb v. Jacob, supra note 2; Ryall v. Rolle, 1 Atk. 194 (1749).
} 
stood in the same way; i.e., as predicated only of an undivided and undistinguishable mass of current money. But money in a bag, or otherwise kept apart from other money . . . is so far earmarked as to fall within the rule on this subject." The more ancient view was thus succeeded by the Ellenborough rule that identification would fail only when the money had been mingled with other money, but as the wronged person was seldom able to point out specifically the exact coins or bills which represented the proceeds of his goods, and since the combined fund could scarcely be regarded as the product of these proceeds, identification was still often impossible. Fortunately for defrauded owners of personalty and cestuis que trust a more liberal interpretation of "identification" has come to prevail and by the adoption of certain tracing methods a beneficiary is accorded an interest in the commingled fund.

The doctrine of tracing misappropriated property into its product has found its greatest utility in situations where the wrongdoer is a trustee or occupies some other fiduciary relation to the legal or equitable owner of the property. The investment by an executor of estate moneys in land, ${ }^{8}$ the purchase of insurance by a fraudulent partner with partnership funds, ${ }^{0}$ the acquisition of securities by the use of trust assets, ${ }^{10}$ come readily to mind. In such situations if the proceeds of the disposition of trust property are deposited in a separate account in a bank to the credit of the defaulting trustee, the equivalent of Lord Ellenborough's money kept apart from other money is found and no further question of identification is raised. Where the trust funds are deposited to the credit of the trustee's personal account in which there is already a balance, the courts have not, for many decades, felt that the means of ascertainment failed as a simple result of such commingling.. II Identification succeeds as long as it is possible to trace such funds into the bank and find

7 Some of the older American cases denied the owner's claim to follow. the proceeds in cases where his chattel was converted by a criminal act. Campbell v. Drake, 4 Ired. Eq. 94 (N. C. 1844); Pascosg Bank v. Hunt, $3 \mathrm{Edw}$. Ch. 615 (N. Y. 1842); Hart $\nabla$. Dogge, 27 Neb. 256 (18S9). The modern view is almost uniformly otherwise. See review of cases in Preston v. Mioore, 133 Tenn. 247, 180 S. W. 320 (1915). See Comment (1928) 37

YALE L. J. 654.

8 Ryall v. Ryall, supra note 3; MrMillan v. MrcMillan, 218 Ala. 559, 119 So. 676 (1929).

9 Shaler v. Trowbridge, 28 N. J. Eq. 595 (1877); Mass. Bonding \& Ing. Co. v. Josselyn, 224 Mich. 159, 194 N. W. 548 (1923).

10 Taylor v. Plumer, supra note 4; Frith v. Cartland, 2 H. \& $\mathrm{Mr} .417$ (1865); In re Oatway, [1903] 2 Ch. D. 356; Glidden v. Gutelius, 96 Fla. 834, 119 So. 140 (1929).

31 But cf. Portland Steamboat Co. v. Locke, 73 MTe. 370 (1882); cf. Banls (of Commerce v. Russell, 2 Dill. 215 (D. Mo. 1873). 
that the tr iree's credit balance consists in part of the credit given for $t$ l: $: \mathrm{m}^{12}$

But whe! from the commingled account, the defaulting "trustee" ${ }^{13}$ makss withdrawals, more difficult problems of identification begin to arise. ${ }^{14}$ To which component of the account should such depletions be attributed? How may it be determined whether or not any balance of credit remaining in the account can be ascribed to the trust funds? The rule of convenience, indicated by the expression "first in, first out," which was adopted for other purposes in Clayton's Case, ${ }^{15}$ was applied by the court in Pennell v. Deffell. ${ }^{16}$ Such a rule presumes that withdrawals from an account are made in the same order that funds are deposited; accordingly the problem of identification is settled by a determination of the condition of the account at the time trust funds were deposited and an examination of withdrawals. ${ }^{27}$ Although this method was subsequently followed ${ }^{18}$ it was finally rejected by the Court of Appeal in Knatchbull v. Hallett, ${ }^{10}$ which has become the classic upon this branch of the subject. In effect, that case held that withdrawals by the trustee for his private purposes were to be ascribed to that part of the combined credit arising from the deposit of his own funds. ${ }^{20}$ It is notable that

12 Thus in Pennell v. Deffell, 4 De G. M. \& G. 372 (1853), the contention that such a blending of funds rendered the trust funds unidentifiable was rejected, and the court proceeded to award a distinctive share in the augmented account to the cestuis, despite the axgument of the insolvent trugtee's creditors that they (the cestuis) should come in as general creditors. Cf. Ex parte Coke, 4 Ch. D. 123 (1876).

13 The word "trustee" is used in this connection in a broad sense to indicate the fiduciary who misappropriates or the converter who is mado a constructive trustee. "Trust" and "cestui" are likewise given broad meanings.

14 The observations herein made in regard to tracing may be appliod equally well, of course, to cases of misappropriation and salo of property, and to cases where a trustee is rightfully in possession of trust estate cash.

15 Devaynes v. Noble, 1 Mer. 528, 584 (1815).

${ }^{26}$ Supra note 12.

${ }^{27}$ Thus, if the trustee's personal account carries a balance of $£ 500$, and he then deposits therein $\$ 500$ of trust funds, followed by a withdrawal of $£ 500$, the balance of $£ 500$ remaining will be attributed to the trust funds. None of the balance, under this rule, would be ascribed to the trust funds if the latter had been deposited prior to the trustee's deposit of his own funds.

${ }^{18}$ Brown v. Adams, 4 Ch. D. 764 (1869).

1913 Ch. D. 696 (1880).

${ }^{20}$ It is te be noted that the sums withdrawn in this case had been spent and were nut capable of being traced. Courts of equity had previously applied a like rule in variant fact situations. Pinkett v. Wright, 2 Hare 120 (1842); Frith v. Cartland, 2 H. \& M. 417 (1865). But upon the trial of this case Justice Fry had considered himself bound by the rule in Penn. il v. Deffell, supra note 12 , although he had no hesitation in expressing his disapproval of it. $13 \mathrm{Ch}$. D. at 699. The Court of Appeal considered that 
in the opinions of both Jessell, M. R., ${ }^{21}$ and Baggallay, L. J., emphasis was placed upon a presumption of the trustee's honesty in withdrawing funds for his own use. The latter even expressed the opinion that, if the balance left in the account were insuficient to cover the amount of the trust funds, the presumption of honesty would necessarily be rebutted and the mechanics of "first in, first out" would apply. While the decision in Knatch bull $v$. Hallett has been widely followed in the United States these latter observations of the judges have had but slight effect upon the American decisions; in a small number of cases consideration of them has led to some confusion. In general, it may be said that the intent of the defaulting trustee is of no importance. ${ }^{23}$

In the preceding cases, the controversy centered about the balance left in an account, the withdrawals having disappeared. If the trustee first withdraws the amount of his own funds, however, and later withdraws the amount of the trust funds, spending the latter but preserving the former intact, is the cestui precluded from setting up an interest in the former? The answer has been that the cestui may follow any withdrawal from that account and claim it or its substitute or product as long as he is able to trace such funds. The case of In re Oatway ${ }^{21}$ illustrates the nature of the cestui's claim upon the combined bank account. There earlier withdrawals were invested in shares by the trustee for his own benefit, and the balance of the account was subsequently expended beyond possibility of finding any substitute. The shares were held to belong to the trust estate. ${ }^{25}$ Accordingly it may be said that the cestui has an equitable claim against, or charge upon, the whole of the "blended" fund represented by the

a correct principle had been abstractly laid down in Pennell v. Defrell, but concluded that the use of the technique of Clayton's Case amounted to a misapplication of the enunciated principle. Ibid. 729 .

21 Ibid. 727.

22 Ibid. 743.

${ }^{23}$ See cases and discussion infra notes 99 to 109 . This is especislly true of an agent or partner who has fraudulently converted the principal's or the partnership property into cash and deposited the same. It would appear ridiculous to hold that his intent.to dissipate a portion of the "Blended" account should deprive the principal or partners of all power to charge the balance of the account with the amount misappropriated.

2s Supra note 10.

${ }^{25}$ Contra: Gering v. Buerstetira, 223 N. W. 625 (Neb. 1929), where the trust claimant was confined to tracing into the balance left in the account and the product of such balance. Similarly, where the mingled banls account exceeded by $\$ 3,700$ the amount of the trust funds deposited therein, and the trustee thereafter drew out $\$ 7,000$ and deposited the same in szother bank, this case permitted the claimant to trace into the account with the second bank only to the extent of $\$ 3,300$. Ibid. 628, 629. The onstructive trust here originated from the fraudulent acceptance of a Jeposit by the initial bank. 
bank account, to the amount of the trust funds, and can successfully assert such claim against any withdrawal from that fund or the product of any withdrawal until the latter has passed to a good faith purchaser. ${ }^{26}$ The remedy of the cestui then depends completely upon an ability to trace the trust fund or the combined fund into specific assets which can be termed the product of such fund.

In the deposit cases cited above, the original chattel or chose in action has, by necessity, been eliminated. What remains for judicial consideration is the substitute-a debt owed by the bank and represented by a balance on the books of the bank to the credit of the depositor. What is the applicability of the principles outlined in this brief survey to the situation where the bank (and not a depositor) stands in a relation to some person which a court will denominate fiduciary? This inquiry arises from the fact that the bank has been entrusted with property of the principal; but the res with which we now become concerned is of a different kind-cash or some one of the many forms of commercial instruments in general use in banking operations. The situations while not identical are quite evidently comparable. ${ }^{27}$

${ }^{26}$ If the trustee or other fiduciary wrongfully deposits fiduciary moneys, properly in his possession, in his own bank account, or if the converter so deposits the proceeds of the conversion, he becomes a constructive trustee of the claim against the bank for the benefit of the wronged cestui or principal. If there was a previous credit in the bank account, it would seem that the cestui should be considered an equitable co-tenant with the constructive trustee, i.e., his interest in the total debt of the bank to the trustee should be proportional to the amount of funds wrongfully deposited by the latter. Hence the wronged person would have an undivided equitable interest in the whole chose, from which it would logically follow that, if one stopped with the constructive trust aspect of the situstion, all deplotions of the credit by the constructive trustee would be of proportional parts of the respective interests of trustee and cestui, and they rould retain their original proportional interest in whatever credit remained. Such was the conclusion reached in Watson v. Thompson, 12 R. I. 466 (1879) (sale of parts of realty in which trustee and cestui were equitrblo co-tenants) where plaintiff proceeded upon the theory of a constructive trust in the combined fund. The concept of an equitable lien, whether expressed or not, is necessary in order to reach the interest of the constructive trustee in the combined credit. But in the banking cases, the finding of a constructive trust is sufficient to permit the cestui to claim successfully any part of the combined fund; equitable lien is an unannounced follower which always attends upon constructive trust. Apparently it need not be pleaded since courts decree the results flowing from such concept although only a trust has been aisserted by claimant.

27 The factual distinctions are interesting, even though they may not call for the application of different principles. In the first instance the bank usually stands indifferent between wronged and wrongdoer, somewhat in the position of a stakeholder; in the second, the bank itself is one of the active principal parties; it is the agent, the fiduciary, the trustee. Ex parto Dale \& Co., 11 Ch. D. 772 (1879), and the subsequent criticism of that 
This article is principally concerned with the applicability of the doctrizes neretofore considered to bank collection cases, i.e., in genera:, cases involving the collection of commercial instruments by a tank for some other person or bank. In the first place, it is plain that if the doctrines are to be applicable some relation which a court will call fiduciary must be found. MTerely an acknowledged relationship of debtor and creditor arising out of $A$ 's handling of $B$ 's chattels will not justify resort to such principles. In the collection cases, the existence of an agency relationship generally supplies the necessary groundwork for the invocation of the doctrines of equitable lien or constructive trust. At times the use of the epithet "trustee ex maleficio" is not wholly inept.

When a customer places commercial paper with his bank for collection, and such bank forwards the same on for collection to a correspondent at the point where the paper is payable, the position of the second bank is, according to the jurisdiction, determined by one of two rules, known respectively as the Miassachusetts and New York rules. According to the former, the second bank becomes the agent of the customer, and, as such, is liable to him for default or neglect in effecting collection; under the New York rule, the second bank is held the agent of the first bank, not of the customer, and so is not ordinarily held responsible to the customer, who must obtain redress in an action against the first bank. The exemption of the second bank from liability at the suit of the customer admits of an exception, however, in case the first bank becomes insolvent and the second has received the customer's paper or the proceeds thereof and refuses to pay the same. ${ }^{28}$ Obviously the same hind of action may be maintained against the collecting bank under the Massachusetts rule, no matter what the condition of the first bank may be. In either case as long as the second bank remains solvent a money judgment against it is sufficient to reimburse the customer. But a different situation presents itself when the second bank fails without having paid over the amount which it has col-

case by the Court of Appeal indicate how the two situations are equated. There the bank collected an item for the claimant and "wrongfully" mingled the proceeds with the bank cash in such manner that they became unidentifiable in specie. The following day the bank failed. Justice Fry, relying upon such cases as Whitecomb v. Jacob and Scott v. Surman, both supra note 2 , held that claimant ras not able to trace his moneg because it had become impossible to identify it in the larger mass. This case was disapproved in Knatchbull v. Hallett, supra note 19, in so far as it held that a cestui could not follow his money into the combined fund. From the incomplete statement of facts given, it does not definitely appear that claimant could have traced the funds in any event.

28 Evansville Bank v. German-American Bank, 155 U. S. 556, 15 Sup. Ct. 221 (1895) ; First Na:"onal Bank of Crown Point จ. First National Bank, 76 Ind. 561 (1881). 
lected and a suit against the first bank for such default cannot be maintained, or if maintainable would not be productive of full reimbursement. The customer may treat the collecting bank as his debtor if he wishes, but banks which have failed have a notorious reputation for liquidating at less than is sufficient to pay creditors in full. Consequently, if the customer is to come out whole, his claim must be classified as preferred, entitling him to priority of payment over general creditors.

Such preferences where given, if not authorized by statute, are made to rest upon some "trust" theory. Plainly the bank effecting collection is an agent in the handling of the paper. Does it cease to be an agent once it has received payment of an item? As has been suggested above, if this question is answered in the affirmative the basis for any theories of equitable lien or constructive trust which would justify the preference is removed at the outset. Wherever the issue has been directly raised the states appear to be about evenly divided on the question; what seems to be the better view holds that once collection has been made, the collecting bank becomes a simple debtor. ${ }^{29}$ The argument is that, as the collecting bank becomes absolutely liable for the amount of the item immediately upon collection, it thereby divests itself of the character of agent and its subsequent handling of the collection proceeds cannot be termed a misappropriation of such funds, irrespective of what is done with them. The imposition of an absolute liability for such amount seems to negative effectively any notion that the obligor was a fiduciary. On the other hand the protagonists of the opposing view insist that the agency (or some other fiduciary) relation continues because an agent is powerless, with respect to the principal's property in his possession, to change the fiduciary relationship which he bears toward that principal without the latter's consent. $^{30}$ An examination of the fact situation is necessary in considering the validity of either view.

${ }^{29}$ See cases cited infra note 35 . If the bank collects at a time when it is insolvent to the knowledge of its officers the result is different. In order to grant relief in such a case, the fiction of withdrawal of authority to collect is utilized and a trust ex maleficio decreed. Hutchinson v. National Bank of Commerce, 145 Ala. 196, 41 So. 143 (1906); Western German Bank v. Norvell, 134 Fed. 724 (C. C. A. 5th, 1905).

so Skinner v. Porter, 45 Idaho 530, 263 Pac. 993 (1928); National Life Ins. Co. v. Mather, 118 Ill. App. 491 (1905); Leach v. Farmers Trust \& Savings Bank, 204 Iowa 1343, 217 N. W. 445 (1928); Bank of Poplar Bluff v. Millspaugh, 313 Mo. 412, 281 S. W. 733 (1926); Hawaiian Pineapplo Co. v. Browne, 69 Mont. 140, 220 Pac. 1114 (1923); Federal Reserve Bank v. Peters, 139 Va. 45, 123 S. E. 379 (1924) ; Foster v. Rincker, 4 Wyo. 484, 35 Pac. 470 (1894). "An agent should not be permitted by its act alono to change the relation by sending its check and so convert its trust fund into a debt." First State Bank v. O'Bannon, 130 Okla. 206, 207, 266 Pac. 472, 473 (1928). 
As typical of collection transactions, one may take that heretofore posed: one bank, either on its own account or for a customer, forwards for collection to another bank an item payable at the locus of the second. The forwarding bank in its covering formletter will advise the second bank that the item is sent "For collection and returns" or "For collection and remittance" or simply "For collection." Current banking practice gives a definite meaning to "returns" or "remittance." It is plain that the use of neither term contemplates that the second bank shall remit to the first the exact medium in which collection is effected. The collecting bank, according to the practically universal custom, is expected to make settlement by transmitting its drait on some other bank or on the first bank, if the second carries an account with the first. If the instructions are simply "For collection" and the first bank does not have an account with the second, remittance is expected in the same way. Consequently it is idle to assume that the collector is expected to lreep the proceeds of the collection separate and apart from its own funds and accounts. ${ }^{32}$ The necessary inference from the usual course of business would seem to be that the agent collecting bank is authorized to convert itself into a simple debtor. The forwarder of the item relies upon the presumed general soundness of the collector as a going business organization and not upon ownership of the specific medium in which payment is made to the collector. He puts his trust, in so far as any particular item is concerned, no less in the general credit standing of the bank than does the purchaser of a draft or a general depositor.

\footnotetext{
" 31 The incongruity of an attempt to justify a holding that the agency relation did not change, because of instructions to "collect and remit" is well illustrated by First State Banls 7. O'Bannon, oupra note 30. Any court which seizes upon the words "and remiztance" and holds them to mean that the very medium of collection is to be sent to the lorwanding banis discloses a surprising ignorance of collection technique. See First National Bank v. Davis, infra note 38. Note the astounding statement of the Kansas court that the words "use the money" are applicable to a collect-and-eredit situation but not to a collect-and-remit trancaction. People's State Banl; $\nabla$. Burlington State Bank, 277 Pac. 39 (Kan. 1929).

$\$$ How little appreciation some courts have of the actualities in the banking cases is illustrated by some of the remarles in Havaiinn Pineapple Co. v. Browne, supra note 30, at 146, 220 Pac. at 1115: " . . the Havro bank [the collector] could only receive cash in payment of the draft [the collection item] and it could only discharge its duty by remitting the cash collected to the Chicago banls." In other pords, the duty can be discharged only in a manner in which a bant is never expected to act (unless specifically instructed so to do), and which is directly contrary to banking practice in every part of the country.

33 This article does not attempt an analysis of the arguments advanced from policy that in every case the fortrarder of a collection item should be entitled to a preference for the amount of a collected but unremitted item upon failure of the collecting banls. These argaments are chiefly
} 
From the technical viewpoint, further questions may be raised. After the collecting bank, as agent or bailee of the principal's property, has performed its duty of changing the collection item into some other form, does the substitute belong to the principal? If the agent's only duty were to retain that exact substitute for the principal no doubt it would be reasonable to consider it the property of the latter. But if it is the further duty of the agent to change the substitute into still another form, and that wother form is the agent's own obligation (evidenced by its draft), obviously the substitute would seem to have gone to pay for the quondam agent's obligation and, by the process of exchange, would seem to belong to the agent. Other questions present themselves: Did the substitute ever become the property of the principal? Or did the agent become a debtor immediately upon making the first conversion? If not at that early moment, then surely the property must cease to be that of the principal when the agent issues some evidence of its obligation. ${ }^{\text {sh }}$ But since the

two: (1) That the owner is forced by business necessity to entrust the handling of his items to a distant institution which he either has no voice in selecting or cannot select upon any intelligent basis; hence that if ho is denied a preference he is made an involuntary creditor of a failed bank upon the same footing with those who freely chose their banking connection; (2) That according the owners of collected items preferential treatment would be productive of considerable economy in the conduct of baink receiverships by eliminating the mass of litigation now flowing through the courts regarding the application of bank assets to the payment of collection claims. Although no data seems to be available on the latter point, a sifting of the banking cases makes it plain that large sums are being oxpended in the course of such litigation. In regard to a specialized situation, namely, where an item is forwarded directly to the drawee bank for payment, Professor R. B. Turner in his article Bank Collections-The Direct Routing Practice (1930) 39 YALE L. J. 468, 487, takes the view that the owner of the forwarded item should always be given a preference in case the drawee's draft in payment remains unpaid because of the failure of the drawee (or in case the collection item has been discharged and the arawee has failed to remit); that the practice of giving preferences in such cases would merely compensate owners for the increased risks othorwise attendant upon the increasing use of direct routing to drawees. Ho regards the contention that the debtor-creditor relation is established by reason of the privilege of the collector to mingle the proceeds and to remit in exchange as an "outworn rationalization in disregard of changing conditions."

34 The principal would seem in effect a purchaser of the agent's draft. The purchaser of a bank draft is a creditor and not a cestui, and is not entitled to a preference in case the issuing bank fails before tho draft is paid. Peterson v. Potter, 46 Idaho 43, 266 Pac. 429 (1928) (cashior's check); Clark v. Toronto Bank, 72 Kan. 1, 82 Pac. 582 (1905) \& MassoyHarris Harvester Co. v. First State Bank, 122 Kan. 483, 252 Pac. 247 (1927) (cashier's check) ; Jourdan v. Bennett, 119 Miss. 576, 81 So. 239 (1919); Leach v. Iowa State Savings Bank, 202 Iowa 95, 211 N. W. 515 (1926); Leach v. Exchange Bank, 203 Iowa 790, 211 N. W. 516 (1926); Andrew v. C. M. \& St. P. Ry., 211 N. W. 515 (Iowa 1926); American 
draft is supposed to be evidence of a previously existing obligation and is merely part of the machinery for effecting a settlement of obligations between the banks, why did not the debtor position of the collector arise before such time?

It has accordingly been held that the proceeds of a collection are not trust funds, ${ }^{35}$ or that they cease to be such when once mingled with the bank's own funds. ${ }^{30}$ Some courts have seized upon an express direction to do that which is always implied (in the absence of contrary instructions) to find that the agency ceases upon collection. Thus, if the collecting bank is instructed to remit in a certain type of exchange, ${ }^{37}$ or authority so to remit can be implied, ${ }^{38}$ the agency has been said to terminate upon collection. Whether the kind of exchange is designated or not should not affect the result reached, for in the absence of

Express Co. ₹. Cosmopolitan Trust Co., 239 MFass. 249, 132 N. E. 26 (1921); Legniti v. Mechanics \& Metals National Banl, 230 N. Y. 415, 130 N. E. 597 (1921) (obiter) ; cf. In re Citizens State Bank, 44 Idaho 33, 255 Pac. 300 (1927) ; Bowman v. First National Bank, 9 Wash. 614, 38 Pac. 211 (1894). Contra, if the bank is insolvent to the knovledge of the oficers at the time the draft is sold: Union State Bank v. People's State Bank, 192 Wis. 28, 211 N. W. 931 (1927).

25 First National Bank v. Williams, 15 F. (2d) 585 (E. D. N. C. 1926); Smith Reduction Corporation v. Williams, 15 F. (2d) 874 (E. D. N. C. 1926) (unless collection is made when insolvent to lenowledge of oficers); Akin v. Jones, 93 Tenn. 353, 27 S. W. 669 (1894); Hallam จ. Tillinghast, 19 Wash. 20, 52 Pac. 329 (1898); Union National Banls v. Citizens Banls, 153 Ind. 44, 54 N. E. 97 (1899); Hecker-Jones-Jervell Irilling Co. v. Cosmopolitan Trust Co., 242 Mass. 181, 136 N. E. 333 (1922); Citizens Bank v. Bradley, 136 S. C. 511, 134 S. E. 510 (1926) ; Peters Shoe Co. v. Miurray, 31 Tex. Civ. App. 259, 71 S. W. 977 (1903).

36 First National Bank v. Wilmington \& W. R. R., 7T Fed. 401 (C. C. A. 4th, 1896) (obiter); Mianufacturers Bank v. Continental Banls, 148 Minss. 553, 20 N. E. 193 (1889); North Carolina Corp. Comm. v. LIerchants' \& Farmers' Bank, 137 N. C. 697, 50 S. E. 308 (1905); cf. Young v. Tentonia Bank \& Trust Co., 134 La. 879, 64 So. 806 (1914); Sabine Canal Co. v. Crowley Trust \& Savings Bank, 164 La. 33, 113 So. 754 (1927). It is sometimes difficult to determine whether the court, in denying a preference, is more impressed by the view that the principal-agent relation ceases upon mingling or by the impossibility of identifying the proceeds in a mixed fund or account. See Bank of Commerce v. Russell, supra note 11. The denial of a preference by a.referee and the conclusion that only a debtor-creditor relationship arose was approved in Fant v. Dinkins, 149 S. C. 363,147 S. E. 312 (1929), the referee basing his conclusion upon acceptance by the forwarder of the collector's draft.

${ }^{37}$ Colorado \& Southern Ry. v. Docking, 124 Kan. 48, 257 Pac. 743 (1927); Akin v. Jones, supra note 35; Sayles v. Cox, 95 Tenn. 579, 32 S. W. 626 (1895). Contra: Darragh Co. v. Goodman, 124 Ark. 532, 187 S. W. 673 (1916); Holder v. Western German Bank, 136 Fed. 9Q (C. C. A. 6th, 1905).

${ }^{38}$ California Pacling Co. v. MrcClintock, 75 Mont. 72, 241 Pac. 1077 (1925) ; First National Bank v. Davis, 114 N. C. 343, 19 S. E. 280 (1894) (express general agreement to "remit daily"). 
other instructions the collecting bank is always expected to remit in a draft on its correspondent. Judicial notice of this custom is taken by the courts of Washington ${ }^{30}$ and New Mexico. ${ }^{40}$ The former state concludes that such a custom destroys the agency relation:

"The custom of bankers in regard to making collections and remittances therefor is so well established and has become so universally known, that knowledge thereof must be imputed to courts; and they are therefore required to take judicial notice of the fact that a bank, when it makes a collection for a foreign correspondent, never, unless specifically directed so to do, remits the specie collected, but, instead, thereof, always takes the specie to its own use; and sends therefor its draft or certificate of deposit. ... If this was the general custom the legal effect of forwarding the collection and directing remittance of the proceeds would be the same as though the money had been paid to the bank for its draft, which it was at the same time required to issue; and such a transaction between a bank and one of its customers has never been held to create any trust relation between such customer and the bank." "1

Similarly, the New Mexico court finds that when the draft has been remitted, the money "drops out of the case as the basis of the relation and the draft" comes in; likewise that there is no equity in favor of the forwarder of the item "superior to that of one, who, having a payment to make at a distant point, paid his money into the bank and received therefor the bank's draft with which to make his remittance." 42

00 Bowman v. First National Bank, supra note 34; Ryer Grain Co. v. American Security Bank, 147 Wash. 42, 264 Pac. 1000 (1928). But of. First National Bank v. Commercial Bank \& Trust Co., 137 Wash. 335, 242 Pac. 356 (1926).

10 State v. McKinley County Bank, 32 N. M. 147, 252 Pac. 980 (1927). The Iowa court has declined to take notice of this custom, or even to give any effect to it although the litigants stipulate its existence, because of a desire not to "complicate" the situation or "disturb well-gettled rules" on the matter. Leach v. City-Commercial Savings Bank, 219 N. W. 496 (Iow\& 1928).

al Bowman v. First National Bank, supra noțe 34, at 618, 38 Pac. at 212.

42. State v. MicKinley County Bank, supra note 40. Requirement of sctual forwarding of the draft was injected into the case in order to reconcile it with First National Bank v. Dennis, 20 N. M. 96, 146 Pac. 948 (1915), where a trust in collection proceeds was decreed, because, "in fraud of the agreement," the collecting bank had made no move to remit before closing its doors. But this requirement was elaborated in Sinclair Refining Co. v. Tierney, 270 Pac. 792,793 (N. M. 1928) where after citing Stato v. McKinley County Bank, supra, the court said: "In the latter case wo held that the status of the collecting bank changed from trustee to debtor when it had collected and had followed instructions by remitting. The converse is true, that a failure to remit in accordance with instructions would result in the status remaining unchanged." See review of New Mexico cases in Board of Commissioners v. People's Bank, 279 Pac. 60 
Whatever objection there may be to divesting the transaction of its fiduciary nature immediately upon collection, it would seem reasonable to assert that, once remittance has been made in the usual or instructed manner, i.e., by bank draft, there is no longer any validity to an attempt to impress a trust character upon the funds. ${ }^{43}$ This is subject to exception, however, where the circumstances are such as would raise a constructive trust or trust ex maleficio in regard to a general deposit, namely, receipt of such funds at a time when the bank was insolvent to the knowledge of its officers. ${ }^{46}$

Turning now to those states which apply the doctrines of trust to the proceeds, even after a credit instrument has been issued as a substitute for them, the initial difficulty of considering such funds as fiduciary funds is generally no difficulty at all; the solvent is the ready assumption that the "trust" character continues. If the bank mingles the collection funds with its own funds, it is assimilated to the position of the defaulting trustee and the preferential recovery by the forwarder is made to depend upon the utilization of certain fictions which have been devised in the course of decision. Failure of the collecting bank to remit is treated as a breach of fiduciary duty and a constructive trust is

(N. R. 1929). In United States National Bank v. Glanton, 146 Ga 786, 92 S. E. 625 (1917), drafts were forwarded for collection, but without instructions as to kind of remittance. The court said: "When the collecting banls sent its check in the usual course of business, no trust existed, but on the contrary ... the relation was simply that of debtor and creditor." The Massachusetts court realistically observed in Hecker-Jones-Jewell Milling Co. v. Cosmopolitan Trust Co., supra note 35: "Ordinarily when $2^{\circ}$ draft has been paid to the collecting banl, the owner's right of control ceases, and the relation between collecting bank and the owner ceases to be that of agent to principal, and becomes that of debtor to creditor."

43 If there is an agreement or understanding that remittance shall be made by "draft", and the bank fails before the draft is paid, the forvarder "is not now in a position to urge a claim of preference by virtue of nonpayment of said draft against the funds in the hands of the receiver." Leach v. Iowa State Savings Bank, 202 Iowa 894, 211 N. W. 517 (1926). ".... where a bank issues its draft with authority and in conformity to instructions the relationship thereafter is that of debtor and creditor, and not of principal and agent or of trustee and cestui que trust.... The rule is quite universal that any agreement or understanding vhereby the bank is to use the identical money collected and substitute its own obligation in its stead, that the theory of a trust does not exist." Leach v. Battle Creek Savings Bank, 203 Iowa 507, 511,-211 N. W. 520, 522 (1926). The Iowa court has had occasion to apply this rule many times in recent years. Leach v. Battle Creek Savings Bank, 202 Iowa 875, 211 N. W. 527 (1926); Valentine v. Andrew, 203 Iowa 463, 212 N. W. 674 (1927); Andrev v. Darrow Trust \& Savings Bank, 204 Iowa 870, 216 N. W. 553 (1927); Leach v. City-Commercial Savings Bank, supra note 40; Leach v. Farmers \& Merchants Savings Bank, 220 N. W. 10 (Iowa 1928).

4 Western German Bank v. Norvell, supra note 29; cf. Finst National Bank v. Williams; Smith Reduction Corp. v. Williams, both supra noto 35 . 
raised in order to bring into play all the remedial devices attaching thereto, as much as if the customer's paper had been converted by a thief. Having thus, by the simple method of ignoring the alternative, determined that the fiduciary relation persists, the only remaining hurdle is that of identification. Up to this point the claimant is permitted to run his course with scarcely the simulacrum of opposition. But here the hazards await him in regimented series. Some, however, are more apparent than real, owing to the availability of the fictions previously mentioned.

Influenced by the "modern rule of equity" as enunciated in Knatchbull $v$. Hallett ${ }^{45}$ and apparently unaware of the limitations implicit in that case, several American courts glossed over the matter of identification of the "trust res" in a substituted form and imposed a lien upon, or raised a constructive trust in respect of, all the assets of an insolvent bank, provided it were merely shown that the bank had received the proceeds of the collection. ${ }^{48}$ The subsequent disposition or identification of any asset as being produced in whole or in part from such proceeds was not a matter regarded as requiring investigation. In so far as the owner of the item and the bank were concerned, the justice of such a result was unquestionable; but where other creditors are concerned the right to take any portion of the assets of an insolvent to the exclusion of such creditors must be rested upon proof that that portion is the property of the claimant or the product of his property. A trust relationship with respect to any particular asset is not to be established by a mere showing that a trustee violated his duty to the beneficiary. And without some identification of assets as the produce of the misapplied funds the claimant has no reason to be treated otherwise than as a creditor. ${ }^{47}$

\footnotetext{
\$5 Supra note 19.

${ }^{46}$ Independent District v. King, 80 Iowa 497,45 N. W. 908 (1890); of. Davenport Plow Co. v. Lamp, 80 Iowa 722, 45 N. W. 1049 (1890). Aleo Bunton v. King, 80 Iowa 506, 45 N. W. 1050 (1890); Peals v. Ellicott, 30 Kan. 156, 1 Pac. 499 (1883); Harrison v. Smith, 83 Mo. 210, (1884); German Fire Ins. Co. v. Kimble, 66 Mo. App. 370 (1896); Thompson v. Gloucester City Savings Inst., 8 Atl. 97 (N. J. Ch. 1887); People v. Bank of Dansville, 39 Hun 187 (1886); Jones v. Kilbreth, 49 Ohio St. 401, 31 N. E. 346 (1892) ; Mcleod v. Evans, 66 Wis. 401, 28 N. W. 173 (1886). Penls v. Ellicott was not a collection case, but the same matter of the identification of trust funds was involved.

47 Compare Multnomah County v. Oregon National Bank, 61 Fed. 912, 914 (C. C. Ore. 1894).: "The so-called right to be preferred in case of wrongful conversion is a right of ownership-a right of property; a right which lays hold of the property whether in its original or in a substituted form; a right which follows the property so long as it can be ascertained to be the same property or its product and only does so because the property to be reached can be ascertained to be the same property or its product. When the means of ascertainment of the identity of property or proceeds
} 
There exists today, outside of some statutes to be noted later, little authority for imposing a lien upon the general assets of an insolvent bank. The Wisconsin cases have been expressly overruled, ${ }^{48}$ those in New York were soon explained away, ${ }^{40}$ and the Iowa court has whittled down most of the rule applied in the case of Plow Company v. Lamp; ${ }^{50}$ the Kansas court has come to the conclusion that its earlier decisions did not inquire closely enough into the matter of identification, ${ }^{5 x}$ and Missouri seems to have receded to some degree from its earlier position. $\$ 2$ The greater number of states by far require that there shall be a tracing of the proceeds of collection into specific assets which come into the possession of a receiver, ${ }^{53}$ a requirement that is sometimes

fail, the right fails." Also Hanover National Bank v. Thomas, 217 Ala. 494, 117 So. 42 (1928): "The equitable right to trace the trust fund and impress the fund with which it has been commingled or the property into which it has been merged, with the trust, is rested upon the right of property and not on a theory of a preference arising from an unlawful conversion." $C f$.

- Leach v. Towa State Savings Bank, 204 Iowa 497, 212 N. W. 748 (1927).

48 Nonotuck Silk Co. v. Flanders, 87 Wis. 237, 58 N. W. 383 (1894).

4 Cavin v. Gleason, 105 N. Y. 256, 11 N. E. 504 (1887).

50 Supra note 46.

${ }^{31}$ Arnold Investment Co. v. Citizens State Bank, 98 Kan. 412, 158 Pac. 68 (1916); Miller v. Viola State Bank, 121 Kan. 193, 246 Pac. 517 (1926); Chetopa State Bank v. Farmers' \& Merchants' Bank, 114 Kan. 463, 218 PaC. 1000 (1923) (obiter). The Kansas cases, hovever, leave much to be desired in the way of clarification.

52 Federal Reserve Bank v. Millspangh, 314 Mio. 1, 282 S. W. 706 (1926).

53 Philadelphia National Bank v. Dowd, 38 Fed. 172 (E. D. N. C. 1889); Merchants' \& Farmers' Bank v. Austin, 48 Fed. 25 (C: C. N. D. Aln. 1891); Mpltnomah County v. Oregon National Bank, supra note 47; Boone County National Bank v. Latimer, 67 Fed. 27 (C. C. W. D. Mo. 1895); City Banls v. Blackmore, 75 Fed. 771 (C. C. A. 6th, 1896); In re Mrulligan, 116 Fed. 715 (D. Mass. 1902); American Can Co. v. Williams, 178 Fed. 420 (C. C. A. 2d, 1910) ; Titlow v. Milcormick, 236 Fed. 209 (C. C. A. 9th, 1916); State Bank of Winfield v. Alva Security Bank, 232 Fed. 847 (C. C. A. 8th, 1916); Anadarko Cotton Oil Co. v. Litteer, 300 Fed. 222 (E. D. Olda. 1924); Nyssa-Arcadia Drainage District v. First National Banl, 3 F. (2d) 648 (D. Ore. 1925) ; First National Bank v. Dickson, 26 F. (2d) 411 (C. C. A. 8th, 1928);; Burnes National Bank v. Spurway, 28 F. (2d) 40 (S. D. Iowa 1928) ; Steele Briggs Seed Co. v. Spurway, 28 F. (2d) 42 (S. D. Iova 1928) ; St. Louis Brewing Ass'n. v. Austin, 100 Ala. 313, 13 So. 908 (1893); Rainwater v. Wildman, 172 Ark. 521, 289 S. W. 488 (1927); Ober \& Sons Co. v. Cochran, 118 Ga. 396, 45 S. E. 382 (1903); Citizens National Bank v. Haynes 144 Ga. 490, 87 S. E. 399 (1915) (special deposit); National Banls of the Republic v. Porter, 44 Idaho 514, 258 Pac. 544 (1927); Woodhouse v. Crandall, 197 IIL. 104, 64 N. E. 292 (1902) (special deposit); Hudspeth v. Union Trust \& Savings Bank, 197 Iowa 913, 193 N. W. 279 (1923); Leach v. Iowa State Savings Bank, 204 Iowa 497, 212 N. W. 748 (1927); Andrem v. Darrow Trust \& Savings Bank, 204 Iowa 870, 216 N. W. 553 (1927); Andrew v. State Bank of New Hampton, 205 Iowa 1064, 217 N. W. 250 (1928) ; Andrew v. Hartley State Bank, 207 Iowa 407, 219 N. W. 929 (1928); Arnold Investment Co. v. Citizens State Bank, supra note 51; Miller $\nabla$. Viola State Bank, supra note 51; Salem Elevator Works v. Com- 
conveniently lightened by the use of well-known trust formulae.

It is therefore surprising to find that some courts have, in comparatively recent cases, decreed trusts and granted preferences to claimants where, by the most liberal construction of ordinary tracing rules possible, one could not reasonably say that it had been shown that any asset possessed by the collecting bank at the time it closed its doors had been produced in any degree by the substitute for the collection item. So far as appears from the reported facts in the Pennsylvania case of Cameron v. Carnegie Trust Co., ${ }^{54}$ there is not the slightest semblance of tracing the claimant's proceeds into the assets of the failed bank; nevertheless a preference was granted. There the collection item was paid in cash. The report is silent as to the amount of cash on hand in the bank at any time, and nothing appears as to any investments made. After determining that a trust ex maleficio arose from the act of mingling the collection proceeds with the bank's money at a time when the bank was insolvent, the opinion continues with a consideration of the passages from Pomeroy set out in the footnotes ss and the court concludes: " . . . admittedly the money belonging to appellant was included in the trust company's general assets which were at all times sufficiently large to make good the amount due, and the

missioner of Banks, 252 Mass. 366, 148 N. E. 220 (1925); Billingsley v. Pollock, 69 Miss. 759, 13 So. 828 (1892); State v. Banking Corporation, 77 Mont. 134, 251 Pac. 151 (1926) ; State v. Bank of Commerce, 54 Neb. 725, 75 N. W. 28 (1898) ; Morrison v. Lincoln Savings Bank \& Safe Deposit Co., 57 Neb. 225, 77 N. W. 655 (1898); Ellicott v. Knhl, 60 N. J. Eq. 333, 46 Atl. 945 (1900) (not a banking case); Daughtry v. International Banls of Commerce, 18 N. M. 119, 134 Pac. 220 (1913); Board of Commissionerg v. Clapp, 24 N. M. 522, 174 Pac. 998 (1918); North Dakota Elevator Co. v. Clark, 3 N. D. 26, 53 N. W. 175 (1892); Hall v. Sullivan, 123 Okls. 233, 253 Pac. 45 (1926); Muhlenberg จ. Northwest Loan \& Trust Co., 26 Oro. 132, 38 Pac. 932 (1894); Yeldell v. People's Bank, 118 S. C. 442, 110 S. E. 789 (1922) ; Plano Mfg. Co. v. Auld, 14 S. D. 512, 86 N. W. 21 (1901); Farmers State Bank v. Smith, 53 S. D. 641, 222 N. W. 143 (1928); North. western National Bank v. James Valley Bank, 63 S. D. 467, 221 N. W. 82 (1928) ; Nonotuck Silk Co. v. Flanders, supra note 48; Lusk Devolopment Co. v. Giinther, 32 Wyo. 294, 232 Pac. 518 (1925).

54292 Pa. 114, 140 Atl. 768 (1928).

55 "If the beneficiary can show that the trustee's estate, as it came into the hands of his assignee, trustee in bankruptcy, receiver, executor or administrator, was actually increased by the whole or a definite portion of the misappropriated trust fund, justice demands that he, and not the other creditors, should have the benefit of this increase. . . . It is now the well settled rule, that where withdrawals from the mixed fund, with or without subsequent replenishing from the trustee's individual money, have not at any time reduced the balance to a sum less than the trust fund deposited, the cestui que trust, as against the trustee's creditors, is entitled to payment in full; his money is sufficiently identified as having always been contained within the blended fund." 3 PoMrroy, EQUiTy JURISprudence (4th ed. 1918) § $1048(\mathrm{e})$. 
effect of refusing relief would be to give to other distributees a. larger sum than they would have received but for the fraud practiced on appellant." It is apparent that the court in makingthis last statement shifts its ground from the cited statement of Pomeroy on which it purports to rely. The Pomeroy statement speaks of withdrawals from a mixed or blended fund, which in the present case could be nothing other than the cash in the bank increased by the addition of the cash received for plaintiff's collection. The reference to the trust company's "general assets" can mean nothing less than the general estate of the company. The court approaches dangerously close to the rejected doctrine of McLeod v. Evans, ${ }^{\text {to }}$ which has met with such general disapproval and which has been disowned in the house of its creator.st -The mere fact that the estate is sufficiently large at all times to pay the amount does not justify the granting of a preference; ${ }^{s a}$ nor does the mere fraudulent conduct of a trustee resulting in the declaration of a trust ex maleficio.s While the attempt to distinguish the case from other Pennsylvania decisions is generally fairly successful on the facts, the court treats the case of Webb $v$. Newhall ${ }^{e x}$ as controlling. This case, however; had an all-important distinguishing feature: the agent (trustee) had deposited the claimant's funds in his own bank account, and the latter at all times constituted a separable asset (or fund) which it was perfectly apparent had been built up in part at least by claimant's funds, and to which, under acknowledged equitable principles, a. lien attached in favor of the claimant.

In Eifel $v$. Vogel, ${ }^{61}$ a note owned by the plaintifi was collected by the bank fifteen months before its failure; settlement therefor was never made; in the opinion nothing appears as to the medium. in which payment was received and there is no attempt made to trace. The court contents itself with the simple statement: "The title to the proceeds of the note did not pass to the bank, but remained in the plaintiff, and as they augmented the assets of the bank to the amount thereof, plaintiff is entitled to have the full amount paid to him." For all that appears the plaintifi's money" might have been expended for bank advertising or contributed to charity..$^{62}$

S6 Supra note 46.

57 Nonotuck Silk Co. จ. Flanders, supra note 48;.cf. Freiberg จ. Stoddnrt. $161 \mathrm{~Pa}$. 259, 28 Atl. 1111 (1894).

58 Thompson's Appeal, 22 Pa. 16 (1853).

50 "A trust creditor merely as such has no preference over others." Webb v. Newhall, $274 \mathrm{~Pa}$. 135, 117 Atl. 793 (1922).

to Supra note 59; of. In re Vosbungh's Estate, 279 Pa. 329, 123 Atl. 813 (1924).

61 169 Minn. 281, 211 N. W. 332 (1926).

62 Although the Eifel case does not discuss the motter of identification, subsequent Minnesota preference cases have considered it in some detail,. 
Equally objectionable was the four to three decision of the Supreme Court of Nebraska in Central National Bank v. First National Bank, ${ }^{63}$ where the owner forwarded four notes to defendant bank for collection. Two of the notes were paid by checks drawn on the collecting bank; one was renewed, the renewal sold, and the proceeds used in some unknown manner by the collector; the fourth was eventually returned to the owner. The owner claimed a preference for $\$ 4,467$; cash on hand in the bank at time of failure was $\$ 1,370$. Upon rehearing, the court's earlier decision was reversed and preferences were accorded the owner for the amount of the first three notes and the collected interest. Rationalization was attempted in this manner: the collecting bank "hid the trust funds in a wilderness of banking assets" where the converted property could not be identified; the proceeds of plaintiff's notes augmented the deposits of the insolvent bank, thus increasing the general assets; the general creditors have no greater rights to plaintiff's converted trust property than defendant; before distribution can be made, the assets must be reduced to a common fund; upon completion of that process all property, real, personal and mixed, must be reduced to money-a single fund in the hands of the receiver; "plaintiff's property, changed in form by fraud, is in that fund." Counsel admitted, and the majority of the court proceeded upon the assumption, that the proceeds could not be traced into any specific assets. The extreme position taken is that if at any time the estate of the insolvent bank has been benefited by the conversion of the principal's property a preference should be granted. Thus: "All that seems to us to be 'manifest,' in considering plaintiff's right to a preference over general creditors, is that it is immaterial whether the converted proceeds were used to purchase the bank building - or reduced the insolvent bank's indebtedness by which items of property were burdened." All necessity of tracing is thus eliminated; a presumption that the 'bank's indebtedness has been reduced by the use of claimant's proceeds will suffice to justify a preference. ${ }^{64}$ But on what theory do the

and, relying upon Stein v. Kemp, 132 Minn. 44, 155 N. W. 1052 (1916), where a literal presumption of honesty was indulged in, have decided that the plaintiff's 'burden of proof goes no further than to require plaintiffs to show that the money actually came into the hands of the bank." Eastman v. Farmers State Bank, 175 Minn. 366, 221 N. W. 236 (1928); cf. Blythe v. Kujawa, 175 Minn. 88, 220 N. W. 168 (1928) (special deposit cases).

${ }^{63} 115$ Neb. 472, 216 N. W. 302 (1927); also 115 Neb. 444, 213 N. W. 745 (1927).

os The court in its opinion after rehearing, it is true, stated that the following principle was adopted: "Where the beneficiary of a trust, in an action to establish a preferred claim as a charge against the general assels of an insolvent bank in the hands of a receiver, traces the trust fund througn 
rights of the claimant with respect to items of property burdened by the general indebtedness of the bank rise any higher than those of the persons who have been paid by the use of claimant's proceeds? Presumably, to follow the majority's line of reasoning, those proceeds have been used to pay depositors, general creditors. On that basis, how can the plaintiff claim more than to be subrogated to the rights of such depositors? The proposition that once the estate has been augmented by the proceeds the right to a preference has been established is, however, not considered tenable by most courts, ${ }^{\circ 0}$ identification by a tracing process being required. ${ }^{\text {or }}$

conversion of the bank into the mass of its assets, the burden of proof is on the receiver ... to prove that the assets pere not augmented by the conversion or that the trust fund disappeared from the assets, if the defence is based on those grounds." But the dissenting opinion on the previous hearing (213 N. W. 747) was expressly adopted as the opinion of the court, and the latter emphatically voices the "principle" that even though the converted proceeds are used for the payment of the banl's indebtedness, the right to a preference continues.

${ }^{65}$ See talk of subrogation in Leach v. City-Commercial Savings Banl;, 219 N. W. 496, 500, 224 N. W. 583 (Iowa 1929).

${ }^{66}$ Commercial National Bank v. Armstrong, 148 U. S. 50, 13 Sup. Ct. 533 (1893) ; Drovers National Bank v. Roller, 85 Md. 495, 37 Atl. 30 (1897) (agent's deposit of trust funds in personal account); State v. Farmers State Bank, 54 Riont. 515, 172 Pac. 130 (1918); White v. Banl, 60 S. C. 122, 38 S. E. 453 (1901); Spokane v. First National Banl, 68 Fed. 979 (C. C. A. 9th, 1895); cases cited supra note 53.

ar Upon a third hearing of this case, the decision upon rehearing was reversed and preference denied; one justice having been replaced, his successor along with the previous minority decided that, inasmuch as the insolvent institution was a national bank, the determination of what vere assets presented a federal question. Accordingly the court held that the course of decision in the federal courts shorred that it "is indispensable to the maintenance. by a cestui que trust of a claim to preferential payment by a receiver out of the proceeds of the estate of an insolvent that clear proof be made that the trust property or its proceeds vent into a specific fund or into a specifically identified piece of property which came to the hands of the receiver, and then the claim can be sustained to the fund or property only and only to the extent that the trust property or its proceeds went into it. It is not sufficient to prove that trust property or its proceeds went into the general assets of the insolvent estate." Central National Bank v. First National Bank, 118 Neb. 161, 162, 219 N. W. 894, 895 (1928). Likewise, in Gering v. Buerstetta, supra note 25, the court talked as if the matter of preference in the case of a failed national banl: must be decided according to the course of decision in the federal courts; but in addition to the citation of federal cases it relied upon its own intermediate decision in State v. Citizens State Bank, 117 Neb. 358, 220 N. W. 593 (1928), where the idea of a general lien attaching to all the assets of the insolvent collecting bank was in effect repudiated and a preference refused where it was impossible to trace. The latter case may be distinguished from Central National Bank v. First National Bank on the tenuous ground that it was affirmatively shown therein how the produce of claimant's collection was dissipated while there was no evidence on that point in the 


\section{MEDIA OF COLLECTION}

Cash. The initial step in the process of identification is, of course, a determination of the medium in which payment of the item has been made. ${ }^{68}$ Assuming that the collecting bank has been taken in charge by a receiver and that settlement for a collection has not been obtained by the forwarder, the latter indisputably traces its property if the cash received has been kept in a separate fund, ${ }^{60}$ or if any of the instruments named in the last. three categories mentioned in the footnote remains unpaid in the possession of the bank and passes to the receiver. Under such conditions the owner is entitled to recover in specie the substitute for the item, and if, after taking charge, the receiver collects any such instrument from the drawee or obligor, he holds its proceeds as a trustee for the owner who may take the appropriato steps to charge him as such. ${ }^{20}$ If cash has been received by the collecting bank and the same has become indistinguishably mingled with the cash of the bank, no difficulty of tracing exists at this point and the owner is entitled to a lien on the mixed fund to the extent of his own contribution. But cash in a bank is not an unvarying component of the bank's resources; it is being continually received and paid out. Here the situation is analogous to that in Knatchbutt v. Hallett, ${ }^{72}$ and the rule of that case has been widely applied by American courts. If the mingled cash fund is reduced by withdrawals in the course of business the lien of the claimant attaches to. the balance remaining. ${ }^{\text {ix }}$

Central National Bank case, all involving a question of buxden of proof. In the Gering case burden of proof was placed on the claimant.

68 The following represent the forms in which the proceeds of a collectlorr are, for the most part, initially found:

(1) Cash.

(2) Check of the payor drawn on the collecting bank.

(3) Check of the payor drawn on some other bank.

(4) Some obligation of the payor which the collecting banls has taken in payment.

(5) Draft or cashier's check of some other bank.

The term "payor" is here used broadly to indicate the person who malees payment whether he be the maker of a note, the drawee of a check or draft, or some other person who makes payment on behalf of the maker, drawee, indorser or other party.

${ }^{60}$ Cf. Corn Exchange National Bank v. Solicitors' Loan Co, $188 \mathrm{~Pa}$. 330, 41 Atl. 536 (1898).

70 American Can Co. จ. Williams, supra note 53. The same holds whoro the receiver collects the item deposited with the bank when known to bo insolvent by officers. Raynor v. Scandinavian-American Bank, 122 Waoh. 150, 210 Pac. 499 (1922). Also where the receiver collects the bailed itom. State v. Farmers \& Mechanics State Bank, 278 Pac. 520 (Mont. 1929) (evidence of identiflcation seems inadequate in this case).

I Supra note 19.

72 See cases cited infra note 74; Walker v. First State Bank, 273 Pac. 
This is no more than saying that if he has a lien on the whole it extends to every part. So long as the combined fund is not reduced to an amount below the amount of the claimant's contribution his preference will bring him out whole. ${ }^{\text {ss }}$ The fiction utilized in the Kmatchbull case that the "trustee" will be considered to have withdrawn his own funds first is peculiarly demonstrable as a fiction in the case of a bank because the minds of officers and tellers never advert to the matter of ownership of the money which they are paying out; nor are they ever concerned with leaving a balance which will be available to any particular "cestui."

But plainly, the lien cannot attach to a bank's cash for an

764 (N. M. 1928) (owing to a confusing stipulation the court treats the payment as having been made in cash); see explanation of this case in Board of Commissioners v. People's Bank, 279 Pac. 60 (N. I5. 1925). The Alabama court rejects the idea that the claimant's cash is in the combined fund and imposes a requirement of almost positive identification. St. Lonis Brewing Ass'n. v. Austin, 100 Ala. 313, 13 So. 908 (1893); Jones จ. Merchants Bank, 209 Ala. 20, 95 So. 274 (1923) (the fact that cash on hand at all times exceeded the amount paid to the bank "does not Eervo the purpose of identification within the purvier of the pertinent rale"). In doing so it necessarily throws over the concept of equitrble lien on the combined fund-cash. A demurrer to a petition, alleging that the banls had on hand at all times, exclusive of deposits subsequently made, a sum in cash in excess of the proceeds of collection, was sustrined in Smith v. Jitontgomery, 209 Ala. 100, 102, 95 So. 290, 292 (1923) where the court snid: "The contrary rule, which requires identification and more than tracing the money into a common fund held by a bank or receiver for a number of claimants has been followed by our court." (In all' the above cases, the medium of payment does not appear, but the opinions proceed as if payment had been made in cash). But a bill, averring that the cash talien over by the receiver "included the sum of $\$ 1,800$ " collected for petitioner $772 s$, of course, held good upon demurrer. Hanover National Banls v. Thomas, 217 Ala. 494, 117 So. 42 (1928). On the tracing point, of. Patels v. Patels, 166 Mich. 446, 131 N. W. 1101 (1911).

${ }^{73}$ In some cases, particularly the older ones, where the medium in which payment was made does not appear, the courts have proceeded upon the assumption that cash was collected and have thereafter examined the condition of the cash account in order to decide the question of a right to a preference. First National Bank of Montgomerg v. Armstrong, 36 Fed. 59 (C. C. S. D. Ohio 1888) (amount of collection vas deducted from statement of cash on balance sheet in order to balance day's business); Boone County National Bank $\nabla$. Latimer, supra note 53 (proceeds received went into the "cash assets" of the bank); In re Johnson, 103 Mich. 109, 61 N. W. 352 (1894) (receiver's answer alleged the collection proceeds were mingled with the bank's own currency in vaults); MicDonald v. American Bank \& Trust Co., 79 Mont. 233, 255 Pac. 733 (1927); State v. Banking Corp., 77 Mont. 134, 251 Pac. 151 (1926); Commercial National Bank v. Davis, 115 N. C. 226,20 S. E. 370 (1894); Herchants National Bank v. Davia, 115 N. C. 233,20 S. E. 371 (1894); Plano Mfg. Co. v. Auld, supra note 53; Schimke v. Smith, 50 S. D. 625, 211 N. W. 461 (1926); Continental National Bank v. Weems, 69 Tex. 489,6 S. W. 802 (1888). 
amount greater than the lowest cash balance in such a mingled fund from the time of mingling until a claim is made or the bank passes to the receiver. ${ }^{74}$ Thus, if the mingled funds total $\$ 10,000$, of which $\$ 2,000$ is attributable to the plaintiff's collection proceeds, and the cash is subsequently reduced by withdrawals to $\$ 1,000$, the lien can attach only to the $\$ 1,000$ balance. Subsequent additions to the $\$ 1,000$ arising from deposits or other banking operations will not be subjected to the claim of plaintiff, ${ }^{75}$ because these additions are in no sense the product of plaintiff's money, nor do they bear any relation to it. If the bank thereafter becomes insolvent with $\$ 2,500$ in cash on hand, the preference will be limited to $\$ 1,000$. The lien may attach to the entire sum of $\$ 2,500$ but it attaches only to the extent of $\$ 1,000$ because a fund $(\$ 1,000)$, upon which there was a lien limited to $\$ 1,000$, has been mingled with $\$ 1,500$ of the bank's own moneys. The subsequent admixture cannot increase the effect of the lien as to that particular fund. ${ }^{73}$ Where the matter has not been urged upon them, and no facts have appeared in evidence as to the cash balance in the interim, some courts have, apparently inadvertently, ignored that phase of the tracing process and assumed that the balance of cash on hand at the closing of the bank was the lowest balance subsequent to the date of the collection. ${ }^{77}$

In applying the rule that the preference will be limited to the smallest amount of cash on hand in the interim, it is apparent to anyone with the slightest familiarity with the conduct of banking operations that a determination of the smallest amount can never be more than an approximation. In general, the only

74 Boone County National Bank v. Latimer, supra note 53; Woodhouso v. Crandall, supra note 53; Skinner v. Porter, 45 Idaho 530, 263 Pac. 998 (1928) ; Leach v. Farmers Trust \& Savings Bank, 204 Yowa 1343, 217 N. W. 445 (1928); Shields v. Thomas, 71 Miss. 260, 14 So. 84 (1893); Stato v. Banking Corp., supra note 53; State v. Bank of Commerce, supra noto 58; Arnot v. Bingham, 55 Hun 553 (N. Y. 1890) (same, plus discounted noto purchased with part of cash).

${ }^{75}$ Board of Commissioners v. Strawn, 157 Fed. 49 (C. C. A. 6th, 1907); Covey v. Cannon, 104 Ark. 550, 149 S. W. 514 (1912); cf. American Can Co. v. Williams, supra note 53; Powell v. Missouri Mining Co., 99 Arls. 553, 139 S. W. 299 (1911).

${ }^{76}$ See cases cited supra note 75.

77 Plano Mfg. Co. v. Auld, supra note 53; Hunt v. Townsend, 26 S. W. 310 (Tex. 1894); Board of Fire Commissioners v. Wilkinson, 119 Mich. 655, 78 N. W. 893 (1889) (deposits); Woodhouse v. Crandall, oupra noto 53 (special deposit); State v. Bank of Commerce, 61 Neb. 181, 85 N. W. 43 (1901); Wallace v. Stone, 107 Mich. 190, 65 N. W. 113 (1895). Tho presumption that cash on hand at closing was derived from collection proceeds when the contrary was not shown has been allowed. Stato $\checkmark$. Bank of Commerce, supra note 53; Murray v. North Liberty Savinga Bank, 196 Iowa 729, 195 N. W. 354 (1923). 
data available will be the bank's own statement of cash. The figure therein contained will represent the amount of cash on hand at the close of each day's business. Determination of the lowest amount to which cash fell or of the highest total it reached between the opening for business on any day and the conclusion of the operating day is impossible, ${ }^{78}$ since withdrawals are constantly being made and deposits received; the total on hand is counted only at intervals and in most cases not until the close of the day's business. The amount entered in the bank's daily statement must necessarily be taken as the only data available on the question of the cash balance on any particular day.

The term "cash" is often used in a conveniently ambiguous manner which sometimes leads to loose-judicial thinking. Thus the term "cash with correspondents" or "cash with other banks" has apparently been treated as literally true upon some occasions; the cash fund of a bank has been conceived as including not only cash on hand in the bank but also the "cash" on deposit in other banks. Consequently, if the proceeds of a collection item have been traced into the cash of a bank, the lien has been presumed to attach to the entire "cash fund" as last described." But the balance standing to the credit of a bank with a correspondent, by the most elementary learning, can have no connection with the specie and currency in the bank's vaults, unless the latter has actually been forwarded to the correspondent for credit. The balance with a correspondent is generally built up by the deposit of commercial paper, by borrowing and by the discount of bills receivable. The assimilation of this balance (which of course is not cash, but merely represents a debt) to cash on hand is entirely unwarranted for purposes of tracing.

In People v. Iuka Stare Bank, ${ }^{80}$ collection was made in a check on the collecting bank, which would by the usual rule be considered equivalent to a payment in cash; thereafter on two different days the cash on hand was less than the amount of the collection. The Illinois Appellate court surmounted that difficulty by adding together the amount of cash on hand each day and the credits with correspondents to ascertain each day's cash total, and on the latter basis accorded the claimant preferential treatment. The reverse of this transaction is illustrated by

${ }^{78}$ Failure of the bank sometimes impinges so closely upon the receipt of cash that no conclusion other than that the cash is still in the bank is reasonable. Union State Bank v. People's State Bank, supra note 34.

${ }^{79}$ State v. Bank of Commerce, supra note 77; People v. Iulis State Bank, 229 Ill. App. 4 (1923). In the first case, there might have been some reason for considering that it was possible to trace into one bank account, but assuredly not into all. Cf. Schimke v. Smith, supra note 73.

${ }^{80}$ Supra note 79. 
People v. Auburn State Bank, , $^{81}$ where payment was received by $A$ bank in checks on $B$ bank; the collector deposited the checks in $C$ bank. In determining the fund from which claimant's claim for a preference could be paid, the court added to the credit on the books of $C$ the amount of cash on hand in $A$ 's vaults; preference was decreed despite the fact that for three days prior to the failure of $A$ the balance with $C$ was less than the amount of the collection. By the simplest of all tracing technique, the proceeds of claimant's items had gone into the balance on the books of $C$ and had (so far as the facts show) not the slightest connection with the cash in $A$ 's vaults. ${ }^{22}$ Most courts are astute enough to realize that in such a situation collection proceeds cannot be traced into both assets. ${ }^{83}$

Another question arises where the claimant can trace the withdrawals of cash into securities held by the bank at the time of failure. In re Oatway ${ }^{84}$ is the analogue of that situation; there withdrawals were made by a trustee from the combined bank account; here withdrawals are made by the bank itself from the combined cash on hand upon which the court impresses a trust or equitable lien. Pursuing the same general reasoning as that later to be applied in the Oatway case, some American courts had already decided that the claimant could follow the withdrawals into the securities and secure a preference with relation to

32215 Ill. App. 133 (1919). Cf. Macy v. Roedenbeck, 227 Fed. 346 (C. C. A. 8th, 1915).

82 The most recent example of this lack of perception is found in Lane v. First National Bank of Vale, 281 Pac. 172, 283 Pac. 17 (Ore. 1929). Compare with this the reasoning in Blythe v. Kujawa, supra note 62, where the receiver admitted that the bank received credit on the books of the correspondent for the item there, in question and that the same theroby immediately became a part of the bank's assets. "Whether the bank thireafter paid out obligations direct over its counter at home or through its Chicago correspondent would not seem important. Whether a man uses his left or his right hand in paying an obligation does not matter. We are unable to make any distinction between the cash funds kept by this bank in its own vault and in.the vault of its Chicago correspondent. The money in either place was a part of the cash holdings of the bank as a whole. And, having at all times since the receipt of this fund had on hand and turned over to the receiver cash more than sufficient to pay this trust fund, neither the receiver nor the general creditors have cause for complaint." 175 Minn. at 95, $220 \mathrm{~N}$. W. at 171 . Cash turned over to receiver was $\$ 13,000$; balance with correspondent was $\$ 353$; a preferred claim for $\$ 4,500$ was allowed.

${ }^{83}$ See cases cited supra now 74 and infra note 95; Board of Commissioners v. Strawn, supra note 75; Walker v. First State Bank, 273 Pac. 764 (N. M. 1928); Gering v. Buerstetta, supra note 25; Andrew v. Hamilton Co. State Bank, 223 N. W. 176 (Iowa, 1929) (draft for $\$ 970$ collected in currency and checks; amount of neither shown; held, no tracing into bank's cash).

84 Supra noto 10. 
them. ${ }^{85}$ Since the lien is on the entire mingled fund, as soon as mingling occurs the lienor can follow all parts of that fund through all their mutations until an innocent purchaser intervenes or until his whole claim is satisfied.

Checks Drawn on Collecting Bant. Payment of collections by checks drawn on the collecting bank have presented some of the most controversial questions in the whole field of tracing. Starting with the proposition that before a preference can be granted there must be a res of some sort in respect to which a fiduciary relation can be established, the first inquiry in any case must direct itself to the question of the existence of such a res. This requirement is sometimes expressed by saying that there must be an "augmentation of assets" of the collecting bank in the first instance; if, in making a collection, there is nothing added to the estate of the bank, there is nothing to which a "trust" an properly be attached. Hence, when the bank makes collecion by taking a check drawn by a customer on his account with ihe bank, the first question is: How have the assets of the bank been increased? An obvious answer is that they have not; by accepting the depositor's check, no tangible res, no chose in action, has been added to what the bank already possessed. The check represents merely a diminution of the total of the bank's liabilities to the extent of the amount for which the check is drawn. For the purposes of establishing a trust and decreeing a lien on specific property, a decrease of liabilities is not an increase of assets. The federal courts uniformly adhere to the proposition that receipt of a check drawn on the collecting bank does not constitute an increase of assets and accordingly deny that a trust is raised in respect to any specific property in the insolvent bank's estate; ${ }^{\text {so a }}$ areference therefore cannot be granted in such a case. A small number of state courts follow the same rule. ${ }^{87}$

8s Arnot จ. Bingham, supra note 74; City of Lincoln v. ILorrison, $64 \mathrm{Neb}$. 822, 90 N. W. 905 (1902); cf. Spokane v. First National Banl, 68 Fed. 979 (C. C. A. 9th, (1895):

${ }^{86}$ Anheuser-Busch Brewing Ass'n. v. Clayton, 56 Fed. 759 (C. C. A. 5th, 1893) ; American. Can Co. v. Williams, supra note 53; Empire State Surety Co. v. Carroll County, 194 Fed. 593 (C. C. A. 8th, 1912), with which of. Mechanics \& Metals National Bank v. Buchanan, 12 F. (2d) 891 (C. C. A. 8th, 1926); Sparks Co. V. Americus National Bank, 230 Fed. 738 (S. D. Ga. 1916) ; Nyssa-Arcadia Drainage District v. First National Banls, supra note 53; Larabee Flour Mills Co. v. National Bank, 13 F. (2d) 330 (C. C. A. 8th, 1926) ; Rorebeck v. Benedict Flour Co., 26 F. (2d) 440 (C. C. A. 8th, 1928) ; Burnes National Bank v. Spurway, 28 F. (2d) 40 (S. D. Iowa 1928) ; Steele Briggs Seed Co. v. Spurway, supra note 53. See the confused attempt to obviate this rule by a resort to the equitable assignment doctrine in Early \& Daniel Co. v. Pearson, 36 F. (2d) 732 (C. C. A. 5th, 1929).

${ }_{87}$ People v. Merchants \& Mechanics Bank, 78 N. Y. 269 (1879); cf. People v. Merchants Bank, 92 Hun 159 (N. Y. 1895); Heclier-Jones-Jevell Hill- 
Other courts disregard the mere form of the transaction and treat payment by check as equivalent to payment in cash. ${ }^{88}$ The grounds for such a treatment are stated in this general manner: The exchange of the check for the collection item is simply a short cut for a more laborious and circuitous process which involves presentment of the check at the paying teller's window, withdrawal of the cash, and then redelivery of the cash at the collection window in payment of the collection item; if the circuitous process were followed, the assets of the bank would undoubtedly be increased by the amount of the cash payment; it is illogical to accord a different effect to one method of payment than to the other. ${ }^{89}$ Hence if the amount of cash on hand in the bank is sufficient to cover the check, payment by check will be treated as if payment had been effected in cash, a not unreasonable conclusion. The claimant is accordingly aided at this point by the adoption of another fiction, namely, that the payor cashed his check and paid the cash back into the bank for the item. Having once adopted and applied the fiction, the subsequent tracing of the collection proceeds takes the course described for tracing the proceeds of a cash payment.

Clearings. A parallel problem is involved in case collection is effected by means of bank clearings. If $X$ bank forwards to $A$ bank checks and other items payable by $B$ bank and $A$ proceeds to collect $X$ 's items by exchanging the latter for checks held by $B$ and drawn on $A$, how can $X$ trace the proceeds of its paper? In effect, $B$ has paid for such paper in checks drawn on $A$. The

ing Co. v. Cosmopolitan Trust Co., supra note 35; Freiberg v. Stoddart, supra note 57; Zimmerli v. Northern Bank \& Trust Co., 111 Wash. 624, 191 Pac. 788 (1920).

${ }^{88}$ State National Bank v. First National Bank, 124 Ark. 531, 187 S. W. 673 (1916); United States National Bank v. Glanton, eupra note 42; Skinner v. Porter, 45 Idaho 530, 263 Pac. 993 (1928); Messenger v. Carroll Bank, 193 lowa 608, 187 N. W. 545 (1922); Leach v. Farmers Savingt Bank, 204 Iowa 1083, 216 N. W. 748 (1927); Leach v. Farmers Trust \& Savings Bank, 204 Iowa 1343, 217 N. W. 445 (1928); Goodyear Tire \& Rubber Co. v. Hanover State Bank, 109 Kan. 772, 204 Pac. 992 (1922) ; Bank of Poplar Bluff v. Millspaugh, supra note 30 (checks forwarded directly to drawee); Hawaiian Pineapple Co. v. Browne, supra note 30; Sinclair Refining Co. v. Tierney, supra note 42; Kansas Flour Mills Co. v. New State Bank, 124 Okla. 185, 256 Pac. 43 (1926) ; First State Bank v. O'Bannon, supra note 30; Mothersead v. Excello Feed Milling Co., 131 Okla. 100, 267 Pac. 833 (1928) ; Federal Reserve Bank v. Peters, stupra note 30. Preference is denied, however, if the account of the drawer of the check is overdrawn when the check is given. Andrew v. Farmers' State Bank, 203 Iowa 1014, 212 N. W. 124 (1927).

89 "Such a formality [first withdrawing cash and then paying it back into the bank], ordinarily so useless, so contrary to banking custom, would have been entirely superfluous. A court of equity, in the endeavor to determine conflicting rights, is not naturally impressed with a distinction so unsubstantial." Sinclair Refining Co. v. Tierney, supra note 42, at 793. 
identity of this situation with that in which an individual pays by his check on $A$ would be plain if the clearings between the two banks exactly balanced. In that event, one could say that $A$ had collected $X$ 's paper by a simple reduction of its own indebtedness, viz., the amount of the checks drawn on $A$, and that there had been no increase in $A$ 's assets upon which a trust could be imposed. Or, one could indulge in the fiction that $B$ had presented its checks to $A$, received the cash therefor, and then repaid the same to $A$ in exchange for $X$ 's items drawn on $B$. The first result could well be achieved by application of the federal rule that there had been no augmentation of assets, payment having been effected through the medium of checks drawn on the collecting bank. The Kansas court chose to apply the other theory and permitted $X$ to trace the proceeds of its items into $A$ 's cash. ${ }^{90}$ In this case the balance of clearings was against $A$, and hence $A$ had actually paid to $B$ its draft for the difference, in addition to turning over the checks drawn on $B$. This fact did not affect the result, however, once the fiction had been applied. $B$ was presumed to have paid $A$ the amount of $X$ 's checks in cash, and so long as the cash on hand in $A$ continued to equal or exceed the amount of $X$ 's items, $X$ had a lien on such fund.

But what is the technique of tracing in case the balance is in favor of $A$ ? To illustrate: $A$ presented to $B$ items totalling $\$ 3,224$, in which was included $X$ 's paper to the amount of $\$ 2,923$. $B$ paid these clearings with checks drawn on $A$ for $\$ 2,338$, with checks on $R$ bank (for which $A$ acted as clearing agent) for $\$ 353$ and a draft on $Z$ for $\$ 533$. The draft on $Z$ was deposited to the credit of $A$ 's account with a correspondent and the balance in that account never thereafter fell below \$533. The checks on $R$ were charged to $R$ and constituted a valid claim against that bank. Cash in $A$ at all times exceeded $\$ 3,000$. The court took the view that $X$ 's funds were never mingled with the funds in $A$ bank, that its money was plainly traced in part to the payment of $A$ 's debts (i.e., checks drawn on $A$ ), and that there was

${ }^{90}$ Kansas State Bank v. First State Bank, 62 Kan. 788, 64 Pac. 634 (1901). Contra: Nyssa-Arcadia Drainage District, supra note 53; First National Bank v. Williams, supra. note 35; Smith Reduction Corp. v. Williams, supra note 35; Farmers National Bank v. Pribble, 15 F. (2d) 175 (C. C. A. 8th, 1926) ; Rorebeck v. Benedict Flour Co., supra note 86; Burnes National Banls v. Spurway, supra note 86; Steele Briggs Seed Co. v. Spurway, supra note 53; Leach v. Iowa State Savings Bank, supra note 47; Leach v. City-Commercial Savings Bank, 207 Iowa 1254, 219 N. W. 496 (1928); Leach v. Mechanics Savings Bank, 211 N. W. 506 (Iowa 1926); Northwestern National Bank v. James Valley Bank, supra note 53; Birch v. International State Bank, 50 S. D. 60, 208 N. W. 167 (1926). The same result as in the Kansas case was reached in Bauck v. Veigel, 225 N. W. 916 (Minn. 1929), where the balance of clearings was in favor of $A$. It was held that the claimant was entitled to trace the amount of its collection nto $A$ 's cash, the checks received from $B$ being considered as the equivalent 
no connection between the cash in $A$ and the paper of $X .^{91}$ This amounted to an adoption of the federal rule regarding augmentation. But the court held that $X$ 's proceeds were distinctly traced into $A$ 's account with its correspondent where the $\$ 533 \mathrm{draft}$ was deposited and into whatever sum the receiver should be able to recover from $R$ on the claim.

In People's National Bank v. Moore, ${ }^{92}$ the balance of clearings in favor of $A$ exceeded the amount of $X$ 's items and was paid by a draft on $B$ 's correspondent. $X$ was held "entitled to impress a trust upon" the draft and its proceeds for the amount of his checks. $^{93}$ The cash on hand in $A$ at the time of failure is not considered ; the court treats the total of $A$ 's clearings as a mingled fund and raises the hackneyed presumption that the trustee "did that which was lawful, and therefor made his payments out of his own portion of the fund." Therefore, "applying the principle of these cases, it must be presumed, in the absence of evidence to the contrary, that the People's National Bank $(A)$ applied to its debts due to the Stockman's Bank $(B)$ the obligations belonging to the People's National Bank, and received the draft as representing, in part, the amount of plaintiff's checks." As the federal rule precludes the use of the fiction that payment by check is equivalent to payment in cash, it is plain that a preference would have to be denied unless it were possible to prove that the proceeds of the plaintiff's checks were traceable into some other asset which came into the receiver's hands. In this instance the plaintiff chose the draft of $B$ as that asset. Is it possible to show, with or without the aid of the presumptions which have been heretofore discussed, that the proceeds of $X$ 's checks are capable of being traced into the draft?

In the first place, it is well to note that there is no mingled

of cash. In addition the claimant received the cash with which $B$ had paid $A$ for the balance of clearings running against $B$.

91 Warren Paving Co. v. Dunn, 8 App. Div. 205, 40 N. Y. Supp. 209 (3d Dep't 1896).

8225 F. (2d) 599 (C. C. A. 8th, 1928).

${ }^{93}$ Accord: Nyssa-Arcadia Drainage District v. First National Bank, supra note 53; cf. Dickson v. First National Bank, supra note 53; Leach v. Iowa State Savings Bank, supra note 47; Leach v. City-Commercial Savings Bank, supra note 90. In People's State Bank v. Burlington Stato Bank, 277 Pac. 39 (Kan. 1929), claimant's item drawn on $B$ was for $\$ 4000$, the balance of clearings in favor of $A$ was $\$ 4580$, and the draft given by $B$ in payment therefor was distinctly traceable. Preference was granted for $\$ 4000$ although nothing appears in the opinion as to what items other than the $\$ 4000$ one were included in $A$ 's clearings on $B$.

94 Without considering the problem of tracing into the draft, the Iowa court denies a preference if there is no evidence of the disposition of tho draft; before a preference can be allowed, it must be found in the hands of the collecting bank or traced into cash or a bank deposit. Leach v. CityCommercial Savings Bank, supra note 90. 
fund in this case. When $X$ 's checks were bundled together with checks belonging to $A$ for presentment for payment, there was no mingled fund; $X$ 's checks were capable of positive identification; all that occurred up to the time that the checks on $B$ were paid was that a number of separate and easily distinguishable pieces of paper were bundled together under one rubber band; the resultant was not a "confused mass" of mingled funds. Accordingly $A$ did not exchange a mingled fund (upon which $X$ had a lien) for a certain number of checks on itself plus $B$ 's draft. Nor was the product of the use of $X$ 's checks and $A$ 's checks a single distinct piece of property. The detailed result of what occurred was that a certain distinct part of $A$ 's property plus a certain distinct part of $X$ 's property was exchanged to $B$ for a reduction of $A$ 's general indebtedness plus a draft on $B$ 's correspondent. It is impossible to say what checks were used to buy $B$ 's draft and what were devoted to the reduction of $A$ 's indebtedness. The presumption that first withdrawals will be attributed to the funds of the trustee does not apply, because first, there is no mingled fund, and second, there was only one withdrawal (if that term is apt). It is plain that the court is either applying with steadfastness a general presumption that the trustee was honest and paid its indebtedness with its own checks, or is creating a new presumption which must be described somewhat like this: $A$ received the total of its clearings in cash; on that fund $X$ had a lien because the total cash fund included the payment for $X$ 's checks; thereafter $A$ used that mingled fund for the purpose, inter alia, of buying $B$ 's draft on $B$ 's correspondent; since $B$ had a lien on the mingled fund, it will have a lien on the draft and the proceeds of the draft. The first presumption, i.e., the presumption of honesty, differs in its application from that usually stated in that it is not concerned. with a mingled fund. It amounts to this: if it is known that a trustee has bought a certain bit of property either out of trust funds or out of his own funds, but it is not known definitely from which, it must be presumed that he purchased it from the trust funds if the cestui chooses to claim it as the proceeds or product of trust funds, a proposition that is logically insupportable in the absence of evidence that the trustee's personal funds and the trust funds were mingled prior to purchase. The other possible presumption set out cannot well be adopted in the federal courts because it would do violence to the course of decision on the effect of payment by check. On the whole, the most that can be said is that $A^{\prime}$ 's indebtedness was reduced by the combined use of $X$ 's checks and $A$ 's checks, and that the draft on $B$ was purchased by the combined use of the same checks, and that it is impossible to attribute one to the other even by the employment of the usual presumptions which cling 
to "equitable lien." However, the "mingling" of the checks in clearing is probakly too nearly identical with a mingling of cash to expect that any distinction will be taken between them; a distinction in treatment of claimants on such a basis certainly wisuld not appeal to a layman, nor indeed to courts. But it is clear that without making the combined use of checks the equivalent of the mingling of cash all possibility of tracing disappears.

Other Commercial Paper. Where the collecting bank accepts in payment of commercial paper placed with it for collection the check of the payor drawn on another bank or a bank draft not drawn upon itself further tracing questions arise. Many of these, which would be simple of solution to a banker, often confuse the courts. If the drawee of the check or draft so received is located in the same city or town, the instrument may be traced through the local clearing process until an exchange of checks is completed; thereafter, the problems previously discussed will present themselves. If the drawee of the instrument is located elsewhere, the collector will usually proceed to secure payment in one of the three following ways:

(1) Forward the payment item to a correspondent for credit.

(2) Forward the payment item directly to the drawee for remittance.

(3) Forward the payment item to someone other than the drawee for collection and remittance.

It is self-evident that if any one of these three methods is followed there can 'be no tracing into the first collecting bank's cash on hand. In using the first method the draft is converted into a credit on the books of the correspondent and the situation thereafter is the simple one of tracing the trust funds into (and out of) the bank account of the trustee. The owner of the original item can impress a "trust" on the account of the collector with the correspondent, ${ }^{05}$ but the same will be subject to the usual rules regarding tracing and withdrawals. The claimant will not be preferred to an amount in excess of the lowest balance in the collecting bank's account. ${ }^{\circ}$ Therefore if that account is ever overdrawn between the day of the deposit and the time when the collecting bank closes, all claim of constructive trust or equitable lien vanishes, ${ }^{07}$ and the claimant will

${ }_{93}$ Commercial National Bank v. Armstrong, 148 U. S. 50, 13 Sup. Ct. 533 (1893); Titlow v. McCormick, 236 Fed. 209 (C. C. A. 9th, 1916); Hutchinson v. National Bank of Commerce, 145 Ala. 196, 41 So. 143 (1906); Hall v. Beymer, 22 Colo. App. 271, 125 Pac. 561 (1912); State v. Farmers' State Bank, 54 Mont. 515, 172 Pac. 130 (1918); Pennington v. Third National Bank, 114 Va. 674, 77 S. E. 455 (1913); Foster v. Rincker, 4 Wyo. 484, 35 Pac. 470 (1894); cf. Colteaux v. First Trust \& Savings Bank, 52 S. D. 443, 218 N. W. 151 (1928); Kleve v. State, 227 N. W. 218 (N. D. 1929). See Board of Commissioners v. People's Bank, supra note 72, at 65. 
not be entitled to a preference out of other balances or funds, "as they do not appear to have been derived in any measure from the proceeds" of the instrument.98 If the second or third method is followed, the drawee or correspondent will in the usual course remit to the collecting bank in its draft and thereafter the collecting bank must again embark upon one of the three enumerated processes in order to collect the payment draft. If the original collecting bank fails while the payment draft is in transit, the collection proceeds are of course traced into that draft.

\section{PRESURIPTION OF HONESTY}

The unnecessary injection ${ }^{90}$ of a presumption of honesty into the cases of Pennell $v$. Deffell.100 and Knatchbull v. HaL lett ${ }^{101}$ in order to justify the results there achieved has not always led to happy results in other cases where there has been a strict adherence to the implications of a literal presumption of honesty. Taking at face value the usual statement that in the absence of evidence to the contrary, the court will presume the trustee intended to observe his trust and leave the trust funds intact, it has sometimes been thought that the converse was necessarily true, namely, that if it were shown that the trustee acted without regard to his trust or in violation thereof, it could not reasonably be supposed that he intended to withdraw

of Titlow v. MrcCormick, supra note 95; State v. Farmers' State Banl, supra note 95; Gering v. Buerstetta, supra note 25; cf. Anadarlio Cotton Oil Co. v. Litteer, supra note 53; State Bank of Winfield v. Alva Secarity Bank, 232 Fed. 847 (C. C. A. 8th, 1916); American Can Co. v. Williams, supra note 53; Miller's Appeal, $218 \mathrm{~Pa}$. 50, 66 Atl. 995 (1907). But of. Macy v. Roedenbeck, supra note 81. As to tracing see Shar v. IrcCord, 18 S. W. (2d) 200 (Tex. Cív. App., 1929).

or Titlow v. MicCormick, supra note 95; Farmers State Bank v. Smith, supra note 53; Salem Elevator Works v. Commissioner of Banlis, supra note 53; Groff v. City Sảvings Fund \& Trust Co., 46 Pa. Super. Ct. 423 (1911) (trust res deposited with correspondent).

${ }^{88}$ State v. Farmers State Bank, supra note 95. See also note 94. If the correspondent exercises a power to charge off the balance and apply the same on the indebtedness of the collecting bank to it, such action, of course, precludes granting of a preference. City Bank v. Blackmore, 75 Fed. 771 (C. C. A. 6th, 1896) ; Dickson v. First National Bank, supra note 53; Leach v. Iowa State Savings Bank, supra note 47; Shav v. Lamar County, 12 S. W. (2d) 607 (Tex. Civ. App. 1928). Collateral released by such application, however, is charged with the lien. Gering v. Buerstetta, supra note 25 , at 630 .

99 Unnecessary, in that there was precedent for attaining a like result without resorting to any such presumption. Pinkett $v$. Wiright, supra note 20.

1 ou Supra note 16.

i01 Supra note 19.

102 Baggallay, L. J., even gave expression to such a view in Knatchbull v. Hallett, supra note 22 . 
his own funds and leave those equitably belonging to the cestui, and, therefore, that tracing into the balance of a mingled account must fail. ${ }^{102}$ Thus, where the bank obviously acted in flagrant disregard of the duty which it owed the co-owner of a collection item the Washington court declined to presume honesty and its concomitant-intention to withdraw (expend) first the funds belonging to the bank and leave intact those of the co-owner. ${ }^{103}$ In Philadelphia National Bank v. Dowd ${ }^{104}$ the court well pointed out the improbability that misappropriated funds remained in a bank's cash although the cash fund never fell below the amount of the former. Any fiction of intention is rebutted by fact; "the officers of the bank had no intent to make any difference between the money collected for their correspondents and that passed over the counters of the bank by depositors." Having effectively eliminated any idea of intent to preserve the collection proceeds, obviously the claimant cannot point out the particular currency received for his collection; so tracing fails and a preference is denied.

But today the presumption of honesty is recognized as a fiction, a device to explain a result. When its use will obtain preferential treatment for a claimant he will utilize it; but when its implications would deny him a favored position he gets closer to the actualities of the situation and proceeds to trace his funds, ignoring, in so far as tracing is concerned, the fact that the trustee was dishonest. As the cases of Amot $v$. Bingham, ${ }^{103}$ City of Lincoln v. Morrison, ${ }^{106}$ and In re Oatway ${ }^{107}$ indicate, the intent of the trustee is immaterial; he may even intend to despoil the trust estate, but that fact will not even retard the tracing process and the award of a preference. If it has any effect, it will, in most cases, aid the claimant. In the case of In re A. O. Brown \& Co., ${ }^{108}$ Hand, J., clearly discerned "equitable lien" camouflaged by the screen labelled "presumption of honesty" and brought it out into the open in this passage:

\footnotetext{
${ }^{103}$ Rugger v. Hammond, 95 Wash. 85, 163 Pac. 408 (1917). This case is illustrative of the lack of knowledge of banking methods so frequently exhibited in judicial decisions. Here the court in investigating what becamo of collection proceeds wanders widely, devotes most of its attention to the checks drawn against the account of the person who was credited with tho proceeds, and wonders what became of the balance in that account, forgetting the proceeds entirely. More recent opinions of the Supreme Court of Washington in banking litigation are characterized by a highly enlightened understanding of banking operations and the methods followed. $C f$. Vickers v. Machinery Warehouse Co., 111 Wash. 576, 191 Pac. 869 (1920); Ryer Grain Co. v. American Security Bank, supra note 39.

10438 Fed. 172 (C. C. E. D. N. C. 1889).

105 Supra note 74.

106 Supra note 85.

${ }^{07}$ Supra note 10.

108189 Fed. 432 (S. D. N. Y. 1911).
} 
"Upon that chose in action [the mingled bank account] the beneficiary has a lien, if he wishes to assert it, equal to the sum of money which his property has contributed to it. So in this case the claimants may elect to retain a lien upon the total deposit after the first withdrawal. This is the effect of the case of Knatchbull v. Hallett. . . a case which has been very frequently cited and the decision of which has been followed many times. This is sometimes stated as a presumption of the trustee's intent, but that is a fiction." 100

It would be well if the presumption of honesty should go the way of all outworn machinery; its use is no longer necessary and persistence in its enunciation may only retard proper analysis of the fact situation to which it is applied. It has well served its purpose, but now that the day of its usefulness is passed it should be consigned to the realm of the forgotten.

\section{CONCLUSION}

Tracing the proceeds of a collection item should be a relatively simple matter. The confusion which the courts have frequently made of cases involving tracing must be attributed in the main to two causes: first, lack of knowledge of banking technique on the part of the courts, and second, similar lack of knowledge and inadequate preparation of cases by counsel. An attempt to trace collection proceeds into cash on hand when payment has been made by check on a distant bank is as inexcusable as failure to offer evidence of cash on hand when payment has been made by a check on the collecting bank. Addition of credits with correspondents and cash on hand in order to determine the fund from which a preference can be paid is simply ridiculous, if tracing means anything at all. The accounting problems involved in tracing are slight, and any banker could readily determine whether or not collection proceeds were identifiable in their original or substituted form if the matter were presented to him for solution.

Lack of understanding on the part of courts and the legal profession has no doubt frequently resulted in disgust at the whole requirement of tracing and has expressed itself in a desire for some simple method of adjusting preferred claims and eliminating the technicalities, which are presumed to be very involved. Some recent legislation seems to have been based upon a desire to arrive at a simple, clear-cut definition of the positions of the various parties without reference to the justice of the results obtained. Outstanding examples are found in North Carolina ${ }^{230}$

\footnotetext{
108 Ibid. 434.
}

110 N. C. CODE (1927) c. 14, §218. Cf. Whitaker Co. v. Whitten, $197 \mathrm{~N}$. C. 251,148 S. E. 239 (1929). 
and Georgia ${ }^{111}$ where legislation eliminates the details of tracing collection proceeds by granting to the owner of a collected but unremitted collection a lien upon all the assets of the collecting bank, dating from the time of collection.112 Such legislation, framed without regard to the equities of the situation, is more or less a throw-back to the doctrine of McLeod v. Evans. ${ }^{113}$ In attempting to avoid the presumed, but non-existent, difficulties involved in the tracing process, it goes to the other extreme and provides a harsh penalty for the general creditors of an insolvent bank in order to favor "trust" creditors who cannot point to any res and say, "This was produced by the use of my money."

The considerations involved in seeking preferential payments have been discussed largely as if the whole matter were a problem of property. And it cannot be doubted that such it essentially is. But it is not intended to suggest here that some other more economical basis might not be found for dealing with the relations arising out of the transactions herein detailed. Some statutory rules might be devised which would simplify the procedure and yet retain all the essential requirements of identification. More economical administration in the liquidation of insolvent banks might be attained, at least in some degree, by the elimination of the litigation that always attends a receiver as a result of the doubtful status of collection items. But it is believed that the statutes cited go too far in throwing overboard the entire principle of identification. And it is further believed that the law on the subject is, in many jurisdictions, becoming well enough defined not to require a rejection of that principle in order to avoid litigation.

${ }^{111}$ GA. ANN. CoDE (Michie Supp. 1928) §2366 (70).

112 Arkansas has attempted to give statutory form to the usual rules regarding the tracing of collection proceeds. ARK. DIG. STAT. (Supp. 1927) $\S 716$.

${ }^{113}$ Supra note 46. 